\title{
AKTIVITAS PEMASARAN PRODUK TABUNGAN PADA PT. BANK PERKREDITAN RAKYAT GAJAH TONGGA KOTO PILIANG SILUNGKANG
}

\author{
Yosefrisal, Mariani St.B Tanjung \\ Akademi Keuangan dan Perbankan Padang \\ mstbtanjung@gmail.com
}

\begin{abstract}
ABSTRAK
Penelitian ini bertujuan untuk mengetahui 1) Bagaimana proses penghimpunan dana pada PT. BPR Gajahtongga Kotopiliang Silungkang. 2) Bagaimana proses pemberian kredit pada PT. BPR Gajahtongga Kotopiliang Silungkang. 3) Bagaimana aktivitas pemasaran produk tabungan PT. BPR Gajahtongga Kotopiliang Silungkang. Penelitian ini bersifat deskriptif dengan mengunakan metode analisa kualitatif, yaitu dengan menganalisa aktivitas pemasaran produk dari PT. Bank Perkreditan Rakyat Gajahtongga Kotopiliang silungkang. Aktivitas pemasaran produk tabungan pada PT. Bank Perkreditan Rakyat Gajahtongga Kotopiliang Silungkang terdiri dari kegiatan menghimpun dana dan pemberian kredit. Dana yang dihimpun yaitu berbentuk tabungan tamades dan deposito berjangka waktu 1 bulan, 3 bulan, 6 bulan, 9 bulan dan 12 bulan. Penyaluran Pemberian kredit pada PT. Bank Perkreditan Rakyat Gajahtongga Kotopiliang Silungkang berbentuk kredit investasi, kredit modal kerja dan kredir konsumsi. Perkembangan penghimpunan dana PT. Bank Perkreditan Rakyat Gajahtongga Kotopiliang Silungkang mengalami peningkatan tiap tahunnya baik penghimpunan tabungan maupun deposito. Penyaluran pemberian kredit pada PT. Bank Perkreditan Rakyat Gajahtongga Kotopiliang Silungkang juga meningkat tiap tahunnya. Dalam melakukan pemasaran produk bank PT. BPR Gajahtongga Kotopiliang Silungkang menerapkan Bauran Pemasaran yang dikenal dengan 7P yaitu Product, Price, Promotion, Distribution/Place, People, Process, dan customer service.
\end{abstract}

Kata Kunci: Aktivitas Pemasaran

\section{PENDAHULUAN}

Secara umum lembaga keuangan dapat dikelompokkan dalam dua bentuk yaitu bank dan bukan bank. Undang-undang RI No. 10 Tahun 1998 Tentang Perbankan mengemukakan bahwa bank adalah Badan usaha yang menghimpun dana dari masyarakat dalam bentuk simpanan dan menyalurkannya kepada masyarakat dalam bentuk kredit atau bentuk-bentuk lainnya dalam rangak meningkatkan taraf hidup rakyat banyak. 
Bank juga badan usaha yang bertugas sebagai lembaga perantara keuangan yang berfungsi menyalurkan dana dari pihak yang kelebihan dana kepada pihak yang membutuhkan dana atau kekuranga dana.

Bank juga badan usaha yang memberikan kredit dan jasa-jasa dalam lalu lintas pembayaran dan peradaran uang yang pemberian kreditnya dilakukan dengan modal sendiri atau dengan dana pihak ketiga yang disimpan di bank, maupun dengan mengedarkan alat-alat pembayaran baru berupa uang giral.

Dalam melakukan kegiatan perekonomian dibutuhkan dana yang cukup besar, sehingga pemerintah mampu menciptakan langkah-langkah baru di bidang perekonomian dengan tujuan dapat mencapai sasaran pembangunan dan pertumbuhan ekonomi. Pemerintah juga harus mampu menciptakan kebijakan-kebijakan agar bank tersebut dapat dimanfaatkan oleh pelaku ekonomi.

Bank memerlukan kebijaksanaan perusahaan yang mendukung terlaksananya fungsi utama bank dan untuk memasarkan produk dan jasanya. Selain itu kebijaksanaan pemasaran diperlukan karena terjadinya liberalisasi di bidang perbankan yang telah mendorong munculnya bank-bank baru dan cabang-cabang bank asing di Indonesia, sehingga persaingan antar bank dalam memperebutkan pasar perbankan semakin ketat. Jika sebelumnya bank tidak pernah melakukan kegiatan pemasaran maka saat ini bank dituntut untuk melakukan pemasaran secara aktif dengan mendatangi calon anggota nasabah dari berbagai jenis bank dirumah maupun dikantoran yang disertai dengan promosi dimedia-media, sehinga bank dapat menyesuaikan diri dengan perkembangan yang ada dan dapat bersaing dengan bank-bank lainnya.

Pemasaran merupakan salah satu aspek yang sangat penting dalam keberhasilan suatu perusahaan perbankan. Pemasaran merupakan pelaksanaan kegiatan-kegiatan usaha dari prosedur kepada konsumen. Pemasaran adalah kegiatan manusia yang diarahkan untuk memuaskan kebutuhaan dan kegiatan melalui proses pertukaran.

Pemasaran bank merupakan penciptaan pelayanan yang memuaskan bagi nasabah di satu pihak dan menguntungkan perusahaan atau bank di pihak lain. Pemasaran bank juga merupakan pemikiran yang berorientasi kepada nasabah, sehingga melalui pelayanan dari bank, kebutuhan dan keinginan nasabah dapat terpenuhi. Dengan kata lain, yang menjadi sasaran pemasaran adalah nasabah. Penyediaan keinginan dan kebutuhan terhadap produk bank ini harus dilakukan melalui perencanaan yang matang, baik untuk perencanaan jangka panjang maupun jangka pendek sehingga memudahkan terjadinya kegiatan pemasaran.

Dalam praktek perbankan di Indonesia, berdasarkan kepada UndangUndang RI No. 7 tahun 1992 tentang Perbankan yang telah diubah menjadi Undang-Undang RI No. 10 tahun 1998 tentang Perbankan, terdapat dua buah bentuk bank berdasarkan jenisnya, yaitu Bank Umum dan Bank Perkreditan Rakyat.

Bank Umum adalah Bank yang melakukan kegiatan usahanya secara konversional atau berdasarkan prinsip syariah yang dalam kegiatannya memberikan jasa lalu lintas pembayaran. Sebagaimana halnya fungsi dan 
tugas perbankan di Indonesia. Bank Umum juga merupakan agent of development yang bertujuan meningkatkan pemerataan, pertumbuhan ekonomi dan stabilitas nasional kearah peningkatan kesejahteraan rakyat banyak.

Sedangkan Bank Perkreditan Rakyat adalah Bank yang melaksanakan kegiatan usahanya secara konvensional atau berdasarkan prinsip syariah yang dalam kegiatannya tidak memberikan jasa dalam lalu lintas pembayaran.

Bank Perkreditan Rakyat mempunyai kegiatan usaha yang lebih terbatas dibandingkan dengan Bank Umum. Bank Perkreditan Rakyat hanya menerima simpanan dalam bentuk Deposito berjangka, Tabungan, dan bentuk lain yang dipersamakan dengan itu dan tidak menerima penghimpunan dana dalam bentuk giro. Bank Perkreditan Rakyat juga tidak di perbolehkan melakukan penyertaan modal, kegiatan usaha dalam modal asing serta kegiatan perasuransian.

Bank Perkreditan Rakyat pada mulanya diarahkan untuk mendorong pertumbuhan dan modernisasi ekonomi pedesaan. Dengan semakin berkembangnya kebutuhan masyarakat, tugas Bank Perkreditan Rakyat tidak hanya ditujukan untuk masyarakat pedesaan, tetapi juga mencangkup penyediaan jasa perbankan bagi masyarakat golongan ekonomi menengah kebawah di daerah perkotaan.

Berdasarkan dari uraian di atas penulis tertarik untuk membahas lebih lanjut dalam bentuk penelitian dengan judul "Aktivitas Pemasaran Produk Tabungan Pada PT. Bank Perkreditan Rakyat Gajahtongga Kotopiliang Silungkang”.

Berdasarkan latar belakang diatas dapat dirumuskan masalah sebagai berikut:

1. Bagaimana proses penghimpunan dana pada PT. BPR Gajahtongga Kotopiliang Silungkang.

2. Bagaimana proses pemberian kredit pada PT. BPR Gajahtongga Kotopiliang Silungkang.

3. Bagaimana aktivitas pemasaran produk tabungan PT. BPR Gajahtongga Kotopiliang Silungkang.

\section{METODE PENELITIAN}

Objek Penelitian

Yang menjadi objek dari penelitian adalah PT. Bank Perkreditan Rakyat Gajahtongga Kotopiliang silungkang, yang berlokasi di Pasar Inpres Silungkang Blok A Lantai Atas, Silungkang - Sumatera Barat 27431. Telp (0755) 91345 Fax. (0755) 91533.

\section{Jenis dan Sumber Data}

Dalam metode penelitian ini digunakan 2 jenis data, yaitu:

a. Data primer adalah data-data yang diperoleh dari wawancara langsung pada pihak yang bersangkutan pada PT. Bank Perkreditan Rakyat Gajahtongga Kotopiliang silungkang 
b. Data sekunder adalah data-data yang diperoleh secara tidak langsung dari sumber-sumber lain di antaranya artikel dan data-data tertulis serta data-data tambahan yang diberikan oleh pihak bank.

\section{Teknik Pengumpulan Data}

Untuk mengumpulkan data-data yang di perlukan dalam penelitian ini, maka dilalukan pengumpulan data dengan cara:

a. Field Research (Studi Lapangan)

Pada studi lapangan, penulis melakukan studi langsung ke PT. Bank Perkreditan Rakyat Gajahtongga Kotopiliang silungkang agar didapatkan data-data serta keterangan-keterangan yang diperlukan dalam penelitian.

b. Library Research (Studi Kepustakaan)

Mengumpulkan data-data dan teori-teori yang berkaitan dengan masalah yang dibahas melalui literatur-literatur yang ada baik berupa buku-buku atau pun majalah-majalah ilmiah yang berkaitan dengan penelitian.

\section{Teknik Analisa}

Penelitian ini bersifat deskriptif dengan mengunakan metode analisa kualitatif, yaitu dengan menganalisa aktivitas pemasaran produk dari PT. Bank Perkreditan Rakyat Gajahtongga Kotopiliang silungkang

\section{LANDASAN TEORI \\ Pengertian Bank}

Undang-Undang RI Nomor 10 tahun 1998 tentang Perbakan mengemukakan bahwa bank adalah badan usaha yang menghimpun dana dari masyarakat dalam bentuk simpan dan menyalurkannya kepada masyarakat dalam bentuk kredit dan atau bentuk-bentuk lainnya dalam rangka meningkatkan taraf hidup rakyat banyak.

Menurut Undang-Undang No 10 Tahun 1998 tentang perbankan, berdasarkan jenisnya bank terbagi atas dua bentuk, yaitu :

1. Bank Umum

Bank Umum adalah bank yang melaksanakan kegiatan usaha secara konversional dan/atau berdasarkan prinsip syariah yang dalam kegiatannya memberikan jasa dalam lalu lintas pembayaran. Adapun kegiatan usaha yang dilakukan Bank Umum adalah :

a. Menghimpun dana dari masyarakat dalam bentuk simpanan berupa Tabungan, Giro, Deposito Berjangka, Sertifikat Deposito dan/atau bentuk lainnya yang dapat dipersamakan dengan itu.

b. Memberikan kredit.

c. Menerbitkan surat pengakuan utang.

d. Membeli, menjual atau menjamin atas resiko sendiri maupu untuk kepentingan dan atas perintah nasabahnya.

e. Memindahkan uang baik untuk kepentingan sendiri maupun untuk kepentingan nasabah (transfer).

f. Menempatkan dana pada, meminjamkan dana dari, atau meminjamkan dana kepada pihak lain, baik dengan mengunakan 
surat, sarana telekomunikasi maupun dengan wesel tunjuk, cek dan sarana lainnya.

g. Menerima pembayaran dari tagihan atas surat berharga dan melakukan perhitungan dengan atau antara pihak ketiga.

h. Menyediakan tempat untuk menyimpan barang dan surat berharga (safe deposite box).

i. Melakukan kegiatan penitipan untuk kepentingan pihak lain berdasarkan suatu kontrak (custodian-ship).

j. Melakukan penempatan dana dari nasabah kepada nasabah lainnya dalam bentuk surat berharga yang tidak tercatat di bursa efek.

2. Bank Perkreditan Rakyat (BPR)

Bank perkreditan Rakyat adalah bank yang melakukan kegiatan usaha secara konvensional dan/atau berdasarkan prisip syariah yang dalam kegiatannya tidak memberikan jasa dalam lalu lintas pembayaran.

Adapun kegiatan-kegiatan yang dilakukan BPR adalah :

a. Menghimpun dana dari masyarakat dalam bentuk simpanan berupa tabungan dan deposito berjangka dan/atau bentuk-bentuk lainnya.

b. Memberikan kredit.

c. Menyediakan pemberian kredit dan penempatan dana berdasarkan prinsip Bank BPR sesuai dengan ketentuan yang telah ditetapkan oleh Bank Indonesia (BI).

d. Menempatkan dananya dalam bentuk Sertifikat Bank Indonesia (SBI), tabungan, dan/atau deposito berjangka pada bank lain.

\section{Pengertian Manajemen Pemasaran Bank}

Pemasaran merupakan salah satu dari kegiatan-kegiatan pokok yang dilakukan oleh perusahaan dalam usahanya untuk mempertahankan kelangsung hidupnya, untuk berkembang dan mendapatkan laba. Berhasil tidaknya dalam pencapaian tujuan bisnis tergantung pada keahlian perusahaan tersebut di bidang pemasaran, produksi keuangan maupun di bidang lain. Selain itu juga tergantung kepada kemampuannya untuk mengkombinasikan fungsi-fungsi tersebut agar organisasi dapat berjalan lancer.

Secara umum pengertian manajemen pemasaran bank menurut Kasmir (2006:143) adalah "Suatu proses perencanaan, pelaksanaan, dan pengendalian dari kegiatan menghimpun dana, menyalurkan dana, dan jasa-jasa keuangan lainnya dalam rangka memenuhi kebutuhan, keinginan, dan kepuasan nasabahnya."

Tujuan dari pemasaran Bank menurut Hasibuan (2007:144) adalah :

1. Mendorong tercapainya tujuan bank

2. Meningkatkan kepercayaan masyarakat kepada bank

3. Menginformasikan sarana-sarana penabungan dan jasa-jasa kredit yang diberikan bank

4. Memperbesar penarikan dana dan penyaluran kredit bank

5. Memperbesar daya saing.

Dari pengertian tersebut dapat diuraikan bahwa manajemen pemasaran bank merupakan usaha untuk memenuhi kebutuhan dan 
keinginan para nasabahnya terhadap produk dan jasa perbankan, baik produk simpanan dan kredit atau jasa-jasa bank lainnya. Penyediaan keinginan dan kebutuhan produk bank ini harus dilakukan melalui perencanaan yang matang, baik untuk perencanaan jangka pendek maupun jangka panjang.

\section{Bauran Pemasaran (Marketing Mix)}

Bauran pemasaran (Marketing mix) merupakan kegiatan pemasaran yang dilakukan secara terpadu. Artinya kegiatan ini dilakukan secara bersamaan di antara elemen-elemen yang ada dalam marketing mix itu sendiri. Setiap elemen tidak dapat berjalan sendiri-sendiri tanpa dukungan dari elemen yang lain. Oleh karena itu setiap elemen membutuhkan strategi tersendiri, namun tetap akan terkait denga strategi pada elemen lainnya.

Bauran pemasaran (marketing mix) menurut Philip kotler adalah "Campuran variable-variable pemasaran yang dapat digunakan oleh suatu perusahaan untuk mengejar tingkat penjualan yang dinginkan dalam pasar sasaran".

Bauran pemasaran (Marketing mix) terdiri dari tujuh (7P) hal yaitu:

1. Produk (product)

Produk adalah apa saja yang dapat ditawarkan kedalam pasar untuk diperhatikan, dimiliki dan digunakan atau di konsumsi sehingga dapat memuaskan keinginan atau kebutuhan dan termasuk didalamnya objek fisik, jasa, orang, tempat, organisasi atau gagasan.

Sehingga produk yang dihasilkan harus dapat memuaskan kebutuhan dan keinginan pemakai. Dalam hal ini bank harus memahaminya karena nasabah pintar membandingkan produk bank dengan produk bank lainnya.

Secara umum terdapat dua macam produk bank yaitu :

A. Produk penghimpunan dana, adalah :

a. Tabungan (Saving Deposito)

Simpanan dana pihak ketiga pada bank yang penarikanya hanya dapat dilakukan denga syarat-syarat tertentu yang disepakati, tetapi tidak dapat ditarik dengan cek, bilyet giro atau lainnya yang dipersamakan dengan itu. Maksud penyimpanannya adalah untuk menabung, oleh sebab itu frekuensi pengambilannya sangat rendah. Setoran untuk tabungan umumnya juga dalam jumlah yang relatif kecil karena berasal dari sebagian pendapatan yang disisikan untuk ditabung. Biasanya tabungan merupakan salah satu sarana promosi bagi pemerintah agar masyarakat melakukan penghematan dengan cara menabung, oleh karena itu penabung lebih banyak terdiri dari perorangan.

b. Deposito (Deposite)

Deposito adalah simpanan yang penarikannya hanya dapat dilakukan pada waktu tertentu berdasarkan perjanjian nasabah penyimpan dengan bank. Pada umumnya jangka waktunya adalah 1 Bulan, 3 bulan, 6 Bulan, 12 Bulan, dan 24 Bulan. Untuk 
mempermudah nasabah dalam perpanjang jangka waktu depositonya bank memberikan fasilitas perpanjangan secara otomatis.

Dalam praktek sehari-hari dikenakan 3 jenis deposito yaitu :

a) Deposito Berjangka (Time Doposite)

Simpanan penarikannya hanya dapat dilakukan pada waktu tertentu menurut perjanjian antara penyampaian dengan bank yang bersangkutan.

b) Deposito Harian (Deposite On Call)

Simpanan dana pihak ketiga pada bank yang penarikannya hanya dapat dilakukan dengan pemberitahuan terlebih dahulu sesuai dengan kesepakatan pihak bank dengan nasabah.

c) Sertifikat Deposito (Certivicate Deposite)

Deposito yang diterbitkan dengan jangka waktu 1, 3, 6 atau 12 Bulan dan bukti simpanan dari sertifikat deposito tersebut dapat diperjualbelikan pada pihak lain.

c. Giro (Demand Deposite)

Simpanan yang dapat digunakan sebagai alat pembayaran dan penarikannya dapat dilakukan setiap saat dengan megunakan cek, sarana perintah pembayaran lainnya atau dengan cara pemindahbukuan. Cek jenis ini lazim disebut rekening koran. Sifat giro sangat likuid karena dapat ditarik sewaktu-waktu.

B. Produk penyaluran dana, adalah :

a. Kredit Investasi

Kredit yang diperlukan untuk keperluan usaha untuk membangun proyek atau pabrik baru untuk keperluan rahabilitas. Sebagai contoh adalah kredit investasi antara lain untuk membangun pabrik atau mesin-mesin.

b. Kredit Modal Kerja

Kredit yang diperlukan, guna untuk meningkatkan jumlah produksi dalam operasionalnya. Sebagai contoh adalah Kredit modal kerja yang digunakan untuk membeli bahan baku, membayar gaji pegawai atau biaya-biaya lainnya yang berkaitan dengan proses produksi perusahaan.

c. Kredit Konsumsi

Kredit yang digunakan untuk dikonsumsi secara pribadi. Dalam kredit tidak ada penambahan barang dan jasa yang dihasilkan karena memang untuk dimanfaatkan oleh seseorang atau badan usaha. Sebagai contoh adalah kredit mobil pribadi, dan kredit perabot rumah tangga.

2. Harga (Price)

Menurut Kasmir (2006:183) Harga adalah jumlah uang yang dibutuhkan untuk mendapatkan sejumlah kombinasi dari produk dan pelayanannya. Penentuan harga penting untuk diperhatikan, mengigat harga sangat menentukan laku atau tidaknya produk dan jasa perbankan. 
Salah dalam menentukan harga akan berakibat fatal terhadap produk yang ditawarkan. Dalam perbankan penetapan harga adalah penetapan tingkat suku bunga yang terdiri dari bunga simpanan dan bunga kredit. Bunga simpanan merupakan biaya dana yang harus dikeluarkan kepada nasabah sedangkan bunga pinjaman merupakan pendapatan yang diterima dari nasabah. Harga suatu barang dan jasa dapat menentukan pasar, mempengaruhi dan menentukan posisi perusahaan serta penjualan dari produk. Pada umumnya perusahaan sangat hati-hati dalam menghitung biaya untuk menetapkan harga produknya.

3. Promosi (Promotion)

Promosi merupakan sarana dalam menginformasikan jenis produk yang ditawarkan dan berusaha menarik calon konsumen yang baru. Menurut Kasmir (2006 : 183)

Strategi-strategi promosi adalah :

a. Periklanan (Advertising)

b. Kegiatan Promosi Penjualan (Sales Promotion)

c. Kegiatan Publisitas (Public Relation)

d. Pemasaran Langsung (Direct Marketing)

e. Penjualan personal (Personal selling)

Dalam menghadapi persaingan dan memasuki pasar, salah satu faktor penting yang juga merupakan marketing mix yaitu promisi. Hal ini dirasakan dalam keputusan sehari-hari, walaupun suatu barang di produksi dengan kualitas yang baik, harga murah tetapi perusahaan yang berproduksi tersebut tidak melakukan promosi maka produk yang dihasilkan perusahaan kurang dikenal oleh pembeli.

4. Distribusi (Distribution)

Place merupakan gabungan antara lokasi dan keputusan atas saluran distibusi, dalam hal ini berhubungan dengan bagaimana cara penyampaian jasa kepada konsumen dan dimana lokasi yang strategis. Penentuan lokasi bagi industri perbankan lebih di tetapkan kepada lokasi cabang, penentuan lokasi kantor cabang bank dilakukan untuk cabang utama, cabang pembantu atau kantor kas. Penentuan lokasi kantor beserta sarana dan prasarana pendukung menjadi sangat penting, hal ini disebabkan agar nasabah mudah menjangkau setiap lokasi bank yang ada. Demikian pula sarana dan prasarana harus memberikan rasa yang nyaman dan aman kepada seluruh nasabah yang berhubungan dengan bank.

Ada 3 jenis interaksi antara penyediaan jasa dan konsumen, yaitu :

a. Konsumen mendatangi pemberi jasa (perusahaan)

Apabila keadaannya seperti ini maka lokasi menjadi sangat penting. Perusahaan sebaiknya memilih tempat yang dekat dengan konsumen sehingga mudah dijangkau, dengan kata lain harus strategis.

b. Pemberi jasa mendatangi konsumen

Dalam hal ini lokasi tidak terlalu penting, tetapi yang harus diperhatikan adalah penyampaian jasa harus tetap berkualitas.

c. Pemberi jasa dan konsumen tidak bertemu secara langsung 
Berarti service provider dan konsumen berintegrasi melalui sarana tertentu seperti telepon, komputer atau surat. Selama komunikasi antara kedua belah pihak dapat terlaksana.

5. Orang (People)

Dalam hubungannya dengan pemasaran jasa, maka people yang berfungsi sebagai provider sangat mempengaruhi kualitas jasa yang diberikan. Keputusan dalam people berarti sehubungan dengan seleksi, training, motivasi dan manajemen sumber daya manusia.

Untuk mencapai kualitas yang terbaik maka pegawai harus dilatih untuk menyadari pentingnya pekerjaan meraka yaitu memberikan konsumen kepuasaan dalam memenuhi kebutuhannya. Pentingnya people dalam pemasaran jasa berkaitan erat dengan internal marketing yaitu interaksi atau hubungan antara setiap karyawan dengan departemen dalam suatu perusahaan yang dalam hal ini dapat diposisikan sebagai internal customer dan internal supplier. Tujuan dari adanya hubungan tersebut adalah mendorong people dalam kinerja memberikan kepuasan kepada konsumen.

6. Proses (Process)

Proses merupakan gabungan semua aktivitas, umumnya terdiri dari prosedur, jadwal, pekerjaan, mekanisme, aktivitas dan hal-hal rutin dimana jasa yang dilaksanakan akan disampaikan kepada konsumen.

Terdapat empat pilihan yang dapat dipilih oleh marketer, yaitu melalui :

a. Reduced divergence, bararti terjadi pengurangan biaya, peningkatan produktivitas dan kemudahan distribusi.

b. Increased divergence, berarti memperbanyak kustomisasi dan fleksibilitas dalam produksi yang dapat menimbulkan naiknya harga.

c. Reduced complexity, berarti cendrung lebih terspesialisasi.

d. Increased complexity, berarti lebih cendrung kepenetrasi pasar dengan cara menambah service yang diberikan.

7. Pelayanan (Customer Service)

Pengertian customer service secara umum adalah setiap kegiatan yang diperuntukkan atau ditujukan untuk memberikan kepuasan kepada nasabah, melalui pelayanan yang dapat memenuhi keinginan dan kebutuhan nasabah.

Seorang customer service memegang peranan sangat penting disamping memberikan pelayanan juga sebagai pembina hubungan dengan masyrakat atau public relation. Customer service bank dalam melayani para nasabah selalu berusaha menarik dengan cara merayu para calon nasabah agar menjadi nasabah bank yang bersangkutan dengan berbagai cara dan juga harus dapat menjaga nasabah lama agar tetap menjadi nasabah bank. Olek karena itu tugas-tugas yang ditempuh oleh para Customer Service merupakan tulang punggung kegiatan operasional dalam dunia perbankan.

Dari elemen-elemen marketing mix di atas, yang harus diperhatikan pengembangan adalah : 
1. Konsistensi, berhubungn dengan keserasian/kecocokan secara logis dan penggunaannya antara elemen yang satu dengan yang lainnya dalam marketing mix.

2. Integrasi, hubungan yang harmonis antara elemen-elemen tersebut.

3. Leverage, hal ini berhubungan dengan pengoptimalkan kinerja setiap elemen secara lebih secara propesional sehingga lebih mendukung maketing mix untuk mendapatkan daya saing.

\section{ANALISIS DAN PEMBAHASAN}

\section{Bauran Pemasaran Yang Dilakukan PT. Bank Perkreditan Rakyat Gajah tongga Koto piliang Silungkang.}

Usaha-usaha pokok bank perkreditan rakyat haruslah memperhatikan bagaimana cara memasarkan, menjual dan memperkenalkan produknya kepada nasabah dipasaran. Sistem pemasaran yang dilakukan oleh suatu bank dalam memasarkan hasil produksinya secara langsung akan mempengaruhi kelancaran operasi perusahaan tersebut. Karena pemasaran merupakan salah satu dari kegiatan-kegiatan pokok yang dilakukan oleh perusahaan dalam usahanya menciptakan dan menyampaikan jasa bank yang dapat memberikan kepuasan kepada nasabah dengan suatu keuntungan bagi bank. Berhasil tidaknya dalam pencapaian tujuan bisnis tergantung pada keahlian perusahaan dibidang pemasaran, produksi, keuangan maupun bidang lainnya. Selain itu juga tergantung pada kemampuannya untuk mengkombinasikan fungsi-fungsi tersebut agar organisasi dapat berjalan dengan lancar.

Di dalam pencapaian tujuan yang telah ditetapkan dimana memperoleh keuntungan untuk kelangsungan hidup perusahaan sebagai penunjang pembangunan ekonomi daerah, maka PT. BPR Gajahtongga Kotopiliang Silungkang menawarkan dan memasarkan produk-produknya kepada masyarakat.

Bauran Pemasaran (Marketing Mix) :

1. Produk (Product)

Produk merupakan sesuatu baik berupa barang maupun jasa yang dapat memenuhi kebutuhan dan keinginan konsumennya. Dan didalam hal ini PT. BPR Gajahtongga Kotopiliang Silungkang telah melakukan berbagai kebijaksanaan produk agar dapat bersaing dengan produk yang dimiliki oleh para pesaing. Hal ini bertujuan agar produk yang di hasilkan benar-benar merupakan kebutuhan bagi pemakainya, begitu juga dengan kelancaran operasional bank pada gilirannya akan mempengaruhi pencapaian laba yang diharapkan. Untuk mencapai sasaran pemasaran yang terarah pada segmentasi yang dituju dan sesuai dengan keinginan dari masing-masing segmen.

Adapun jenis-jenis produk pada PT. BPR Gajahtongga Kotopiliang Silungkang adalah :

A. Produk Penghimpunan Dana Masyarakat

Sebagai lembaga keuangan, maka dana merupakan persoalan bank yang paling pentin, tanpa dana bank tidak dapat berbuat apa-apa dan tidak 
dapat berfungsi sama sekali. Dana bank adalah uang tunai yang dimiliki bank ataupun aktiva lancer yang dikuasai bank tidak berasal dari bank itu sendiri, tapi juga dari orng lain, uang pihak lain yang "titipkan" pada bank dan sewaktu-waktu akan diambilnya kembali baik sekaligus maupun secara berangsur-angsur.

Yang termaksud dengan dana pihak ketiga adalah dana yang berasal dari luar bank yang dipercayakan oleh masyarakat atau nasabah yang sewaktu-waktu dapat ditariknya kembali. Dana dari pihak ketiga tediri dari :

\section{a. Tabungan}

Tabungan adalah simpanan yang penarikannya hanya dapat dilakukan menurut syarat-syarat tertentu yang di sepakati. Tetapi tidak dapat ditarik dengan cek, bilyet giro, atau alat lainnya yang dipersamakan dengan itu. Tabungan pada PT. BPR Gajahtongga Kotopiliang Silungkang adalah :

TAMADES (Tabungan Masyarakat Desa)

Adapun fasilitas yang dapat diperoleh oleh nasabah adalah :

a) Bunga menarik

b) Pengambilan dan penyetoran dapat dilakukan kapan saja atau waktu kas kantor terbuka

c) Setoran awal minimal Rp 10.000,-

Persyaratan pembukaan rekening tabungan Gajahtongga Kotopiliang Silungkang

a) Mengisi formulir permohonan pembukaan tabungan yang disediakan oleh bank

b) Menyerahkan photo copy KTP atau SIM dan tanda pengenal lainnya

c) Setoran awal minimal Rp. 10.000,-

b.Deposito Berjangka Gajahtongga Kotopiliang Silungkang

Deposito adalah simpanan yang penarikannya hanya dapat yang dilakukan pada waktu tertentu berdasarkan perjanjian nasabah penyimpan dengan bank.

Adapun fasilitas yang dapat diperoleh nasabah adalah :

a) Deposito dalam rupiah

b) Bunga deposito bersaing

c) Bunga dapat diambil setiap bulan atau dipindahbukuan ke rekening tabungan

d) Jangka waktu dapat dipilih antara 1 bulan, 3 bulan, 6 bulan, 12 bulan, 24 bulan. Deposito juga dapat diperpanjang secara otomatis.

Persyaratan pembukaan rekening deposito berjangka Gajahtongga Kotopiliang Silungkang adalah :

a) Menyerahkan photo copy KTP/SIM

b) Mengisi permohonan

c) Menyetorkan setoran awal serta biaya administrasinya

B. Produk Penyuluhan Dana Masyarakat

Jenis-jenis produk penyuluhan dana/kredit yang disalurkan PT. BPR Gajahtongga Kotopiliang Silungkang adalah : 
a. Kredit Investasi

Yaitu pinjaman yang diberikan untuk pembelian barang-barang modal dan jasa yang diperlukan guna rehabilitas, modernisasi, ekspansi relokasi usaha atau pendirian usaha baru.

b. Kredit Modal Kerja

Yaitu pinjaman yang diberikan untuk kepentingan modal kerja debitur nasabah yang bersangkutan atau sebagai modal usaha.

c. Kredit Konsumsi

Yaitu kredit yang diberikan untuk keperluan pribadi atau keperluan konsumsi berupa barang atau jasa yang dibeli, menyewa ataupun dengan cara lain. Biasanya ini khusus untuk pegawai.

2. Harga (Price)

PT. BPR Gajahtongga Kotopiliang Silungkang menentukan tingkat bunga tergantung kepada jenis produk simpanan. Tingkat bunga ditentukan sendiri oleh PT. BPR Gajahtongga Kotopiliang Silungkang. Dengan tingkat bunga pasar, artinya tingkat bunga yang telah ditetapkan oleh PT. BPR Gajahtongga Kotopiliang Silungkang sama dengan tingakat bunga yang ditetapkan oleh bank-bank lain. Pengelolahan biaya bunga merupakan aspek yang paling penting dalam mengelola bisnis, terutama bisnis perbankan.

Adapun tingkat bunga simpanan yang berlaku di PT. BPR Gajahtongga Kotopiliang Silungkang adalah :

a. Tabungan TAMADES (Tabungan Masyarakat Desa)

a) Bunga Menarik

b) Minimal Bunga Rp. 50.000,-(saldo)

c) Setoran awal minimal Rp. 10.000,-

b. Deposito

Bunga deposito $7 \%$

c. Kredit

Bunga Kredit Sebesar 21\%

3. Promosi (Promotion)

Dalam dunia usaha khususnya dalam bidang pemasaran, faktor yang penting untuk membantu dalam usaha mencapai tujuan antara pembelian dan penjual adalah bagaimana komunikasi pemasaran. Secara luas komunikasi pemasaran dapat didefinisikan sebagai suatu kegiatan yang dilakukan oleh pembeli dan penjual, merupakan kegiatan yang membantu dalam pengambilan keputusan serta mengarahkan keputusan dibidang pemasaran serta mengarahkan pertukaran agar lebih memuaskan dengan cara menyadarkan semua pihak untuk berbuat lebih baik.

Salah satu bagian dari proses komunikasi total adalah kegiatan promosi. Promosi merupakan kegiatan perkenalan produk atau jasa yang ditawarkan pada pasar sasaran, kemudian meyakinkan dan mengigatkan konsumen tentang keberadaan produk tersebut dengan tujuan agar mereka membeli produk tersebut.

Dalam usaha PT. BPR Gajahtongga Kotopiliang Silungkang untuk memasarkan produk simpanan pada seluruh lapisan masyarakat, maka 
dapat dilihat kegiatan promosi yang dilakukan oleh PT. BPR Gajahtongga Kotopiliang Silungkang yang meliputi :

a. Mengeluarkan brosur-brosur tentang kegunaan dan ciri khas dari suatu produk dan disini juga akan diperlihatkan tingkat bunga dari masingmasing produk yang ditawarkan.

b. Memberikan hadiah melalui undian-undian yang dilakukan dalam satu kali dalam satu tahun.

c. Memberikan sumbangan-sumbangan sponsor atas kegiatan-kegiatan yang dilakukan oleh pemuda-pemudi diadakan sekitar wilayah PT. BPR Gajahtongga Kotopiliang Silungkang, seperti Tournamenttournament antar kota, seperti : sepak bola, Voly, dan Futsall.

\section{Distribusi (Distribution)}

Penempatan atau pendistribusian produk atau jasa dalam perusahaan bertujuan untuk penyaluran dalam jangka panjang dan menentukan posisi keuntungan secara maksimal. Dalam pendistribusian produk atau jasa-jasa bank, perlu adanya lokasi kantor yang tepat yang didukung oleh pemasaran yang terpadu. PT. Bank Perkreditan Rakyat Gajahtongga Kotopiliang Silungkang melakukan kegiatannya di Pasar Inpres Silungkang Blok A Lantai Atas, Silungkang Sumatera Barat 27431. Telp (0755) 91345 Fax. (0755) 91533. ini dinilai strategis karena berdekatan dengan pasar Silungkang.

Hal ini bertujuan untuk menunjang perekonomian daerah dengan menyalurkan kredit bagi usaha yang bersifat produktif. Untuk kelancaran atau kemajuan perusahaan. Penempatan dan pendistribusian ysng digunakan oleh PT. Bank Perkreditan Rakyat Gajahtongga Kotopiliang Silungkang adalah menggunakan jaringan kerja yang luas. Strategi ini bertujuan untuk mendapatkan nasabah dalam jumlah yang banyak terutama nasabah yang potensial atau yang belum terjangkau oleh bank pesaing.

5. Orang (People)

Merupakan tipe kualitas dan kuantitas orang yang terlibat dalam pemberian jasa. Dalam pemasaran jasa people yang berfungsi sebagai pelayanan jasa sangat mempengaruhi kualitas yang diberikan. Keputusan dalam people ini berarti sehubungan dengan seleksi, perhatian, motivasi dan manajemen sumber daya manusia (MSDM).

Karyawan merupakan hal yang turut menentukan berjalannya kegiatan operasional PT. Bank Perkreditan Rakyat Gajahtongga Kotopiliang Silungkang dalam penghimpunan dana dan penyaluran dana. Karyawan PT. Bank Perkreditan Rakyat Gajahtongga Kotopiliang Silungkang mempunyai tingkat pendidikan yang berbeda-beda dari SLTA sampai Sarjana. Sedangkan aktivitas usaha adalah untuk memberikan pelayanan yang memuaskan bagi nasabah maka PT. Bank Perkreditan Rakyat Gajahtongga Kotopiliang Silungkang selalu memperbaiki kualitas sumber daya manusianya dan terus menambah karyawan yang lebih berkualitas. 


\section{Proses (Process)}

Proses merupakan gabungan semua aktivitas, umumnya terdiri dari prosedur, jadwal pekerjaan, mekanisme, aktivitas hal-hal rutin, dimana jasa dihasilkan dan disampaikan kepada konsumen.

A. Prosedur Pembukaan Rekening Tabungan PT. BPR Gajah tongga Koto piliang Silungkang adalah :

a) Calon nasabah datang menghadapi petugas dan menyatakan maksudnya untuk membuka rekening tabungan baru.

b) Petugas menjelaskan bentuk tabungan yang ada berikut dengan persyaratannya dan selanjutnya meminta persetujuan calon nasabah jika setuju nasabah diminta untuk mengisi permohonan yang telah disediakan oleh PT. BPR Gajahtongga Kotopiliang Silungkang dan menyerahkan kartu identitasnya untuk nantinya dicatat pada specimen.

c) Calon nasabah menyatakan persetujuannya, mengisi blangko permohonan dan menyerahkan kartu identitasnya kepada petugas untuk di catat.

d) Petugas memeriksa pengisian blangko permohonan dan keabsahan kartu identitas nasabah. Selanjutnya mempersiapkan dan meminta nasabah untuk mencantumkan tanda tangannya pada specimen.

e) Nasabah mencantumkan tanda tangannya pada blanko specimen dan menyerahkannya kembali kepada petugas.

f) Petugas memeriksa kembali pencantuman tanda tangan nasabah yang bersangkutan dan mencatatkan data kartu identitas nasabah yang bersangkutan pada blangko spesiment tersebut, menyiapkan nomor rekening dan buku tabungan baru untuk nasabah yang bersangkutan dan meminta nasabah untuk melakukan penyetoran setoran awal melalui kasir dengan menggunakan slip setoran.

g) Nasabah menyetorkan setoran awalnya melalui kasir dengan menggunakan slip penyetoran.

h) Kasir menerima setoran dari nasabah sesuai dengan yang tercantum pada slip setoran, mencantumkan parafnya pada slip setoran dan menyerahkan kembali slip setoran kepada petugas.

i) Petugas mencatatkan setoran nasabah tersebut pada buku tabungan melalui komputer dan kemudian memaraf dan menyerahkan berkas pembukuan rekening baru tersebut (Permohonan, kartu identitas nasabah, spesiment, buku tabungan dan slip setoran) kepada pejabat untuk meminta persetujuan.

j) Pejabat memeriksa berkas di atas dan jika sudah betul langsung memberikan persetujuan dengan mencantumkan tanda tangannya pada specimen dan permohonan nasabah. Kemudian menyerahkan kembali berkas kepada petugas.

k) Petugas menyerahkan buku tabungan dan kartu identitas kepada penabung, menyimpan berkas tabungan baru dan mengumpulkan slip setoran untuk nantinya direkap dan dijilid sebagai bukti pembukuan pada hari yang sama.

Cara pengambilan tabungan adalah : 
1) Tabungan boleh diambil kapan saja pada waktu jam kantor terbuka

2) Pengambilan tabungan dapat dilakukan dengan mengunakan slip pengambilan yang sudah disediakan oleh pihak bank.

\section{B. Proses pembukaan rekening deposito berjangka PT. BPR Gajah tongga Koto piliang Silungkang :}

a) Nasabah datang menemui petugas dan menyampaikan maksudnya untuk membuka rekening deposito baru.

b) Petugas menjelaskan ketentuan dan syarat-syarat pembukaan deposito yang ada dan meminta nasabah untuk menentukan pilihan serta mengisi dan menanda tangani blangko pemohonan.

c) Nasabah setuju dan menentukan pilihannya. Selanjutnya mengisi dan menanda tangani blangko pemohon dan menyerahkan kembali kepada petugas.

d) Petugas memeriksa pengisian blangko dan jika sudah benar maka nasabah menanda tanggani speciment dan menyerahkan kartu identitasnya untuk dicatat pada speciment tersebut.

e) Nasabah menanda tanggani blangko speciment dan menyerahkan kembali kepada petugas beserta kartu identitas.

f) Petugas mencatat kartu identitas nasabah yang bersangkutan kepada speciment, menyiapkan bilyet deposito dan meminta nasabah menyetorkan uang depositonya kepada kasir.

g) Nasabah menyetorkan uang depositonya kepada kasir.

h) Kasir menghitung uang setoran dan mencocokan jumlahnya dengan slip setoran dan nominal deposito pada bilyet itu, jika sudah cocok mencantumkan parafnya pada slip dan bilyet kemudian menyerahkan kembali itu berikut slip setoran kepada petugas.

i) Petugas mencatatkan pembukaan deposito pada buku register deposito dan aplikasi/program komputer, sesuai denga buktinya. Setalah itu menyerahkan berkas deposito yang dimaksud yang berisikan, pemohonan, speciment, kartu identitas nasabah, slip setoran dan bilyet deposito, kepada pejabat yang berwenang untuk diberikan persetujuan.

j) Pejabat yang berwenang memeriksa keabsahan dan pemenuhan persyarakatan formal pembukaan deposito baru dan jika telah benar langsung menanda tanggani bilyet. PT. Bank Perkreditan Rakyat Gajahtongga Kotopiliang Silungkang dan menyerahkan berkas itu kembali kepada petugas.

k) Petugas menyerahkan kembali bilyet deposito asli dan kartu identitas kepada nasabah, menyimpan lembar kedua bilyet untuk bukti pembukuan dan lembar ketiga untuk arsip.

Cara pengambilan deposito adalah :

1) Deposito boleh diambil pada waktu yang telah ditentukan

2) Pengambilan deposito dapat dilakukan dengan mengunakan slip pengambilan yang telah di sediakan oleh pihak bank. 


\section{Proses pemberian kredit pada PT. Bank Perkreditan Rakyat Gajahtongga Kotopiliang Silungkang adalah :}

a) Permohonan kredit

Permohonan kredit menyampaikan maksud untuk permohonan kredit dan kepadanya dijelaskan ketentuan dan syarat-syarat yang berlaku dalam pemberian kredit dan jika yang bersangkutan berkeinginan, kepadanya diminta untuk :

1. Mengisi formulir permohonan kredit yang disediakan oleh bank

2. Menyerahkan dokumen lain yang berupa :

1) Fhoto copy kartu identitas berupa KTP suami dan istri calon debitur yang masih berlaku.

2) Fhoto copy kartu keluarga

3) Fhoto copy BPKB serta STNK kendaraan yang akan dianggunkan

3. Mengisi formulir pendaftaran yang telah di sediakan oleh pihak bank.

b) Survey lapangan

1. Setiap permohon kredit yang masuk akan diproses oleh pihak bank

2. Proses terhadap permohonan ini dimulai dengan mengadakan survey lapangan terhadap sipemohon kredit

3. Waktu pelaksanaan survey lapangan ditentukan oleh pihak bank

c) Analisa dan rekomendasi kredit

1. Setiap pemohonan kredit yang sudah di survey lapangan akan dianalisa oleh account officer

2. Analisa kredit disertai dengan rekomendasi kredit yang sudah dibuat account officer diajukan kepada direksi

d) Administrasi kredit

1. Rekomendasi kredit yang sudah disetujui oleh direksi akan di proses oleh petugas administrasi kredit untuk direalisasikan

2. Petugas administrasi kredit akan mempersiapkan dokumen untuk keperluan realisasi kredit yaitu :

a. Perjanjian kredit antara debitur dengan pihak bank

b. Surat kuasa dari debitur kepada pihak bank untuk pengikatan jaminan

c. Bukti pembayaran yang terdiri dari :

a) Bukti pindahbukuan realisasi kredit

b) Pembayaran provisi, administrasi, asuransi kredit

c) Kartu pembayaran angsuran kredit

3. Mengadministrasikannya secara baik setiap dokumen kredit yang sudah direalisasikan.

7. Pelayanan (Customer Sevice)

Untuk meningkatkan pelayanannya kepada masyarakat atau nasabah, maka PT. Bank Perkreditan Rakyat Gajahtongga Kotopiliang Silungkang yang perlu di perhatikan adalah kepuasan nasabah terhadap pelayanan yang diberikan. Puas artinya nasabah akan merasa tepat semua keinginan dan kebutuhannya dapat dilakukan secara tepat waktu. 
Beikut ini hal-hal pelayanan yang baik dilakukan oleh PT. BPR Gajahtongga Kotopiliang Silungkang adalah sebagai berikut :

a. Tersedia sarana dan prasarana yang baik

Nasabah ingin dilayani secara prima. Untuk melayani nasabah salah satu hal yang paling penting diperhatikan adalah sarana dan prasarana yang dimiliki bank

b. Tersedia personil yang baik

Petugas customer service harus rama, sopan dan santun. Serta cepat tanggap, pandai bicara menyenagkan dan pintar. Petugas customer service harus memikat dan mengambil nasabah, sehingga nasabah semangkin tertarik.

c. Bertanggung jawab kepada setiap nasabah sejak awal sampai selesai

Dalam menjalankan kegiatan pelayanan petugas customer service harus mampu melayani dari awal sampai tuntas atau selesai.

d. Mampu memberikan kepercayaan kepada nasabah

Kepercayaan calon nasabah kepada bank mutlak diperlukan sehingga calon nasabah mau menjadi nasabah bank yang bersangkutan. Demikian pula untuk menjaga nasabah yang lama agar tidak lari perlu dijaga kepercayaannya.

e. Tersedianya komputer sehingga dapat mempermudah dan mempercepat kegiatan operasional bank.

Masalah-Masalah Yang Dihadapi Dalam Penghimpunan Dana dan Pemberian Kredit Serta Cara Penanggulangannya.

Dalam penghimpunan dana dan pemberian kredit tidaklah selalu berjalan dengan lancer seperti yang diharapkan. Seringkali terjadi kendalakendala atau permasalahan baik berasal dari pihak calon nasabah, maupun pihak nasabah maupun pihak bank itu sendiri.

Adapun masalah-masalah yang dihadapi PT. Bank Perkreditan Rakyat Gajahtongga Kotopiliang Silungksng antara lain :

1. Dari Calon Nasabah

a. Masih kurangnya pengetahuan masyarakat mengenai dunia perbankan.

b. Seringkali calon nasabah memberikan informasi yang tidak benar, sehingga mengakibatkan pihak bank harus menganalisa kembali maupun mendata ulang informasi yang diberikan calon nasabah.

c. Seringkali calon nasabah yang mengajukan permohonan tidak memiliki pembukuan, keterangan dan catatan yang lengkap mengenai usahanya, sehinga menyulitkan pihak bank untuk menilai secara akurat tentang usahannya.

2. Dari Nasabah

a. Kredit yang diberikan sering disalahgunakan atau keluar dari tujuan kredit semula

b. Kurangnya keterampilan nasabah dalam memanage usahanya sehingga cendrung rugi 
c. Nasabah mengalami musibah seperti meninggal dunia, sakit-sakitan serta usaha mengalami bencana alam, kebakaran, dan lain-lain sementara bank tidak memiliki asuransi atas usahannya.

Adapun kebijaksanaan yang diambil oleh PT. Bank Perkreditan

Rakyat Gajah tongga Koto piliang Silungkang dalam mengatasi masalah-masalah tersebut antara lain :

1. Menginformasikan PT. Bank Perkreditan Rakyat Gajahtongga Kotopiliang Silungkang kepada masyarakat melalui Koran Singgalang dan Padang Ekspres.

2. Mengadakan penyuluhan-penyuluhan yang dilakukan oleh pegawai bank yang telah dibina. Adapun penyaluhan ini dilakukan di forum kemasyarakatan.

3. Apabila usaha nasabah mengalami kemacetan sehingga nasabah tidak mampu membayar angsuran kreditnya selama tiga bulan berturut-turut, maka PT. Bank Perkreditan Rakyat Gajahtongga Kotopiliang Silungkang membantu nasabah dengan cara :

a. Penjualan Agunan

Penjualan angunan atau asset perusahaan yang dilakukan secara suka rela dalam rangka penyelesaian kredit.

b. Pengambil alihan asset debitur oleh bank

Strategi ini di gunakan dalam rangka penyelesaian pemberian kredit dengan cara mengkompensasikan seluruh hutang debitur atau tanpa keringanan.

c. Keringanan Tungakan Pokok

Upaya penyelesaian kredit dengan penyelesaian kredit melalui pemberian keringanan hutang pokok kepada debitur yang akan melunasinya sekaligus.

d. Likuiditas

Yaitu mengambil kekayaan debitur yang tidak ada hubungannya dengan kegiatan usaha yang dilakukan oleh debitur dan bank dapat melelangnya.

4. Pelaksanaan pengawasan yang disertai dengan pembinaan nasabah.

\section{Perkembangan Jumlah Dana Masyarakat Pada PT. BPR Gajahtongga Koto piliang Silungkang.}

Bank bertugas memberikan pelayanan kepada masyarakat dan bertindak selaku perantara bagi keuangan masyarakat. Oleh karena itu, bank harus selalu berada ditengah masyarakat agar harus uang dari masyarakat yang kelebihan dana dapat ditampung dan disalurkan kembali kepada masyarakat yang kekurangan dana. Dana dari masyarakat yaitu dana yang berasal dari luar bank yang dipercayakan oleh masyarakat atau nasabah yang sewaktu-waktu dapat ditarik.

Pada PT. BPR Gajah tongga Kotopiliang Silungkang dana dari masyarakat hanya berupa deposito dan tabungan. Untuk mengetahui sejauh mana dana masyarakat yang di peroleh oleh PT. BPR Gajah tongga Kotopiliang Silungkang dapat dilihat pada tabel dibawah ini : 
Tabel 1

Perkembangan Penghimpunan Dana Masyarakat

PT. BPR Gajahtongga Kotopiliang Silungkang

Tahun 2008 - 2012

Dalam Ribuan Rupiah

\begin{tabular}{|c|c|c|c|c|}
\hline Tahun & Jumlah & Peningkatan (\%) & Asset & Laba \\
\hline 2009 & 2.468 .783 & 309 & 5.253 .075 & 8.980 \\
\hline 2010 & 5.348 .027 & 117 & 10.537 .987 & 301.089 \\
\hline 2011 & 10.953 .075 & 105 & 18.460 .717 & 418.506 \\
\hline 2012 & 13.875 .519 & 27 & 23.003 .818 & 464.223 \\
\hline
\end{tabular}

Sumber : PT. BPR Gajahtongga Kotopiliang Silungkang

Dari table 1 diatas dapat diketahui posisi dana, asset, laba mengalami peningkatan dari tahun ketahun. Peningkatan penghimpunan dana ini adalah disebabkan karena tingginya kepercayaan masyarakat kepada PT. BPR Gajahtongga Koto piliang Silungkang sehingga mau menyimpan dananya dalam bentuk tabungan dan deposito.

Perkembangan Jumlah Perkreditan Pada PT. BPR Gajahtongga Kotopiliang Silungkang.

Kegiatan bank yang kedua setelah menghimpun dana dari masyarakat adalah menyalurkan kembali dana tersebut kepada masyarakat yang membutuhkannya. Kegiatan penyaluran dana ini dikenal dengan pemberian kredit. Pemberian kredit merupakan tulang punggung kegiatan perbankan, yang bertujuan agar bank dapat memperoleh keuntungan seoptimal mungkin. Sehingga melalui pemberian kredit, bank akan menambah dananya sendiri.

Adapun macam kredit yang diberikan oleh PT. BPR Gajahtongga Kotopiliang Silungkang adalah kredit Investasi, kredit modal kerja dan kredit konsumsi. Untuk dapat melihat perkembangan jumlah kredit yang diberikan oleh PT. BPR Gajahtongga Kotopiliang Silungkang setiap tahunnya dapat dilihat pada tabel 2 dibawah ini :

Tabel 2

Perkembangan Jumlah Kredit Yang Disalurkan PT. BPR Gajahtongga Kotopiliang Silungkang Tahun 2008 -2012

\begin{tabular}{|c|c|c|}
\multicolumn{2}{c|}{ (DalamRibuan Rupiah) } \\
\hline Tahun & Jumlah Kredit & Pertumbuhan (\%) \\
\hline 2009 & 3.485 .139 & 534 \\
\hline 2010 & 7.916 .914 & 127 \\
\hline 2011 & 14.011 .057 & 77 \\
\hline 2012 & 17.762 .410 & 27 \\
\hline
\end{tabular}

Sumber : PT.BPR Gajahtongga Kotopiliang Silungkang

Dari tabel 2 diatas dapat dilihat perkembangan jumlah perkreditan rakyat yang disalurkan oleh PT. BPR Gajahtongga Kotopiliang Silungkang mengalami peningkatan yang cukup berarti, hal ini terlihat dari kenaikan jumlah kredit yang disalurkan kepada masyarakat meningkat pada tahun 
2009 dengan jumlah Rp. 3.485.139,- dengan pertumbuhan sebesar 534\% dan pada tahun 2010 meningkat sebesar 127\%. Begitu pula pada pada tahun 2011 memperlihatkan pertumbuhan jumlah kredit yang disalurkan sebesar $77 \%$ walaupun peningkatan ini tidak sebesar pada tahun 2009 tetapi jumlah kredit yang disalurkan kepada masyarakat tetap meningkat, begitu pula 2012 meningkat sebesar 27\%. Dilihat secara umum maka dari tahun ketahun jumlah kredit selalu mengalami peningkatan dan pertumbuhan terbesar terjadi pada tahun 2009 yaitu sebesar 534\% dengan jumlah kredit sebesar Rp 3.485.139,-. Sedangkan rata-rata peningkatan sebesar $61.5 \%$ setiap tahunnya selama lima tahun terakhir.

\section{KESIMPULAN}

Bank merupakan badan usaha yang menghimpun dana dari masyarakat dalam bentuk simpanan dan menyalurkannya dalam bentuk pemberian kredit atau bentuk-bentuk lainnya untuk meningkatkan taraf hidup rakyat banyak. PT. Bank Perkreditan Rakyat Gajahtongga Kotopiliang Silungkang adalah suatu lembaga keuangan yang bergerak dibidang perbankan.

Berdasarkan atas pemahaman teori dan pembahasan yang dituangkan sebelumnya, dapat dikemukakan beberapa kesimpulan sebagai berikut :

1. Aktivitas pemasaran produk tabungan pada PT. Bank Perkreditan Rakyat Gajahtongga Kotopiliang Silungkang terdiri dari kegiatan menghimpun dana dan pemberian kredit. Dana yang dihimpun yaitu berbentuk tabungan tamades dan deposito berjangka waktu 1 bulan, 3 bulan, 6 bulan, 9 bulan dan 12 bulan. Penyaluran Pemberian kredit pada PT. Bank Perkreditan Rakyat Gajahtongga Kotopiliang Silungkang berbentuk kredit investasi, kredit modal kerja dan kredir konsumsi.

2. Perkembangan penghimpunan dana PT. Bank Perkreditan Rakyat Gajahtongga Kotopiliang Silungkang mengalami peningkatan tiap tahunnya baik penghimpunan tabungan maupun deposito. Penyaluran pemberian kredit pada PT. Bank Perkreditan Rakyat Gajahtongga Kotopiliang Silungkang juga meningkat tiap tahunnya.

3. Dalam melakukan pemasaran produk bank PT. BPR Gajahtongga Kotopiliang Silungkang menerapkan Bauran Pemasaran yang dikenal dengan 7P yaitu Product, Price, Promotion, Distribution/Place, People, Process, dan customer service.

\section{DAFTAR PUSTAKA}

Afrianto, D., \& Afriyeni, A. (2019). Aktivitas Penghimpunan Dana Tabungan Pada PT. Bank Pembangunan Daerah (BPD) Sumatera Barat Cabang Utama Padang. https://doi.org/10.31219/osf.io/ackfh

Andika, A., \& Susanti, F. (2018). Pengaruh Marketing Mix Terhadap Keputusan Pembelian Parfum di Azzwars Parfum Lubeg Padang. https://doi.org/10.31227/osf.io/upgc3 
Aziz, N. (2019). Pengaruh Strategi Promosi Terhadap Keputusan Pembelian Yang Dimediasi Oleh Minat Beli Pada Konsumen Restoran KFC Cabang Khatib Sulaiman Padang. https://doi.org/10.17605/OSF.IO/V92TS

Aziz, N. (2019). Analisis Pengaruh Kualitas Produk, Harga, Promosi Terhadap Keputusan Pembelian Air Minum Dalam Kemasan (AMDK) Merek Aicos Produksi Pt. Bumi Sarimas Indonesia. https://doi.org/10.17605/OSF.IO/8XKYB

F., \& Afriyeni, A. (2019). Aktivitas Pemasaran Produk Tabungan Pada PT. Bank Pembangunan Daerah (BPD) Sumatera Barat Cabang Utama Padang. https://doi.org/10.31219/osf.io/tf2bz

Hasibuan, Melayu S.P, Dasar-Dasar Perbankan, PT. Bumi Aksara, Jakarta, 2007.

Hidayati, R. R., \& Marlius, D. (2018). Aktivitas Promosi Dalam Meningkatkan Dana Pihak Ketiga Pada PT. Bank Perkreditan Rakyat (BPR) Batang Kapas Pesisir Selatan. https://doi.org/10.31227/osf.io/8dgqn

Ikbal, M., \& Marlius, D. (2017). Pengaruh Jumlah Taksiran Dan Uang Pinjaman Terhadap Laba Bersih Pada PT. Pegadaian (UPC) Gurun Laweh. https://doi.org/10.31227/osf.io/uch4a

Jamarnis, S., \& Susanti, F. (2019). Pengaruh Harga Dan Periklanan Melalui Internet Terhadap Keputusan Pembelian Produk Sabun Merek Lux Pada Mahasiswa STIE “KBP” Padang. https://doi.org/10.31227/osf.io/xz3d8

Kasmir, Bank dan Lembaga Keuangan Lainnya, Jakarta; Rajawali Press, 2002.

Kotler, Philip, Manajemen Pemasaran II, Jakarta; PT. Prehalindo, Edisi Millenium, 2002.

Lupioyadi, Rambat,Manajemen Pemasaran Jasa, PT. Salemba Empat, Jakarta, 2001.

Marlius, D. (2017). Keputusan Pembelian Berdasarkan Faktor Psikologis Dan Bauran Pemasaran Pada PT. Intercom Mobilindo Padang. Jurnal Pundi. Volume 1. No. 1. Hal. 57-66. https://doi.org/10.31575/jp.v1i1.9

Marlius, D. (2016). Pengaruh Bauran Pemasaran Jasa Terhadap Minat Nasabah Dalam Menabung Pada Bank Nagari Cabang Muaralabuh. https://doi.org/10.31227/osf.io/vdqgx

Mayliza, R. (2019). Pengaruh Kesadaran Merek, Asosiasi Merek Dan Perception Of Quality Terhadap Keputusan Pembelian Hospital Bed Merek Paramout 
Di PT. Aga Medika Utama Padang (Studi Kasus Rumah Sakit Umum Kota Padang). https://doi.org/10.17605/OSF.IO/VYQ4E

Safitri, R. N., \& Marlius, D. (2017). Penerapan E-Banking Dalam Meningkatkan Jasa Dan Layanan Perbankan Di PT. Bank Rakyat Indonesia Cabang Padang. https://doi.org/10.31227/osf.io/gkv8t

Suhardjono, dan Mudrajad Kuncoro, Manajemen Perbankan, Yogyakarta; BPFE Yogyakarta, 2002

Susanti, F. (2015). Pengaruh Bauran Promosi Terhadap Keputusan Klien Dalam Memilih Radio Carano Sebagai Media Promosi Iklan. https://doi.org/10.31227/osf.io/b9ws7

Susanti, F. (2018). Faktor Faktor Yang Mempengaruhi Minat Beli Pada ECommerce Lazada.co.id (Studi Pada Mahasiswa Jurusan S1 Manajemen "STIE KBP" Padang). https://doi.org/10.31227/osf.io/um4yw

Susanti, F., \& Gunawan, A. C. (2019). Pengaruh Bauran Promosi Dan Harga Terhadap Keputusan Pembelian Produk Kosmetik Maybelline Di Kota Padang. https://doi.org/10.31227/osf.io/npjqh

UU RI No. 10 Tahun 1998 Tentang Perbankan, Jakarta; Sinar Grafika, 1992.

Widayati, R. (2019). Aktivitas Pemasaran Produk Tabungan Pada PT. Bpr Rangkiang Denai Payakumbuh Barat. https://doi.org/10.17605/OSF.IO/S3UZM

Widayati, R. (2019). Aktivitas Pemasaran Produk Simpanan PT. Bank Tabungan Negara (Persero)Tbk Kantor Cabang Padang. https://doi.org/10.17605/OSF.IO/3Z5YC 